УДК 94(100):355(37)“00/01”(091):94(477.7)

Олійник Микола Андрійович

кандидат історичних наук,

Львівський факультет менеджменту і бізнесу

Київського університету культури,

Трускавець, Україна,

kolja4791@gmail.com

\title{
ПРИСУТНІСТЬ РИМЛЯН НА ТЕРИТОРІЇ ОЛЬВІЙСЬКОЇ ДЕРЖАВИ У І-ІІ СТ. Н. Е. В КОНТЕКСТІ ВІЙСЬКОВОЇ ПОЛІТИКИ ДОБИ ПРИНЦИПАТУ
}

Зацікавленість Риму відродженою наприкінці I ст. до н. е. Ольвією була зумовлена, в першу чергу, убезпеченням північно-східних рубежів імперії від набігів сарматських племен та захистом важливих торгівельних шляхів Північного Причорномор'я. Зміцнення кордонів Мезії, яка стала прикордонною провінцією і плацдармом у просуванні римської держави на території грецьких полісів Південної України, а також розуміння важливості Ольвії як найбільшого між західним Понтом і Таврикою античного міста, спонукало римлян підтримати та відновити військовий потенціал цього полісу. Метою цього дослідження і $\mathrm{\epsilon}$ аналіз військової допомоги і присутності римських військ на території ольвійської хори. У статті використано історико-генетичний метод дослідження: послідовно розкрито процес становлення ольвійсько-римських військових зв'язків і причину їх появи. Також з'ясовано важливість Ольвії для Риму в силу іiі зручного географічного розташування як однієї з ланок стримуючої системи північнопонтійських укріплень (limes Olbiopolitanus) задля запобігання нападам варварських племен. Показано, що стратегічний комплекс Нижнього Побужжя слугував віддаленим прикриттям дунайського кордону Римської імперії. Він стримував проникнення варварів на Дунай і забезпечував безпеку сухопутної дороги з Мезії в Таврику. Доведено, що Ольвія посідала важливе місце в системі зовнішньополітичних зв'язків Риму з Херсонесом та Боспорським царством та слідувала у фарватері римської стратегії у даному регіоні. Зроблено висновок, що римська військова присутність в Ольвії сприяла процвітанню і убезпечувала місто від нападів скіфів та сарматів.

Ключові слова: Ольвія, Рим, Moesia Inferior, вексилляція, воїни.

Oliynyk Mykola, Candidate of Historical Scienses, Lviv Faculty of Management and Business of Kyiv University of Culture, Truskavets, Ukraine

The Romans presence on the territory of Olbia state in I-II century A. D. in the context of military policy of the Principate 


\section{ПРИСУТНІСТЬ РИМЛЯН НА ТЕРИТОРІЇ ОЛЬВІЙСЬКОЇ ДЕРЖАВИ У І-ІІ СТ. Н. Е. В КОНТЕКСТІ ВІЙСЬКОВОЇ ПОЛІТИКИ ДОБИ ПРИНЦИПАТУ}

The Rome's interest in Olbia revival at the end of the Ist century B. C. was first of all caused by the need in the Empire's northeastern borders protection from Sarmat tribes raids and the most important trade routes of the Northern Black Sea Coast defense. Moesia borders strengthening being a border province and the base of the Roman Empire advancement on the territory of the Greek city-states in the Southern Ukraine, as well as understanding the Olbia's importance being the biggest ancient city located between west Pontus and Taurica made Romans support and restore military potential of this city-state. The purpose of this research is to analyze the military assistance and presence of the Roman troops on the territory of Olbia chora. The article uses historical-genetic method of research: the process of the Olbia-Roman military relations establishment as well as the reasons for their appearance are being successively explored. We have also discovered the Olbia importance for Rome by vitue of its convenient geographical location being a part of the Northern Pontus stronghold protection system (limes Olbiopolitanus) to prevent invasion of barbarian tribes. The article states that the strategic complex of Lower Pobuzhya served as a remote protection of the Roman Empire's Danube border. It kept barbarians away from entering the Danube and ensured safety of the land routes from Moesia to Taurica. It was proved that Olbia played an important part in foreign policy relations of Rome with the Chersonese and the Bosporan Kingdom, and followed the Roman strategy in this region. It is concluded that the Rome military presence in Olbia contributed to prosperity and protected the city from Scythians and Sarmats attacks.

Key words: Olbia, Rome, Moesia Inferior, vexillatio, warriors.

Олийнык Николай Андреевич, кандидат исторических наук, Львовский факультет менеджмента и бизнеса Киевского университета культуры, Трускавеи, Украина

Присутствие римлян на территории Ольвийского государства в I-II вв. н. е. в контексте военной политики периода Принципата

Интерес Рима к возрождённой в конце I в. до н. э. Ольвии предопределялся, в первую очередь, ограждением северно-восточных рубежей империи от набегов сарматских племён и защитой важних торговый путей Северного Причерноморья. Укрепление границ Мёзии, которая стала приграничной провинцией и плацдармом для продвижения римской державы на территории грецких полисов Южной Украины, а также понимания важности Ольвии как самого большого между западным Понтом и Таврикой античного города, побуждало римлян поддержать и возобновить военный потенциал этого города. Целью исследования и есть анализ военной помощи и присутствия римских войск на территории ольвийской хоры. В статье использованы историко-генетический метод исследования: последовательно раскрыт процесс становлення ольвийско-римских военных связей и причина их появления. Также 


\section{ПРИСУТНІСТЬ РИМЛЯН НА ТЕРИТОРІЇ ОЛЬВІЙСЬКОЇ ДЕРЖАВИ У І-ІІ СТ. Н. Е. В КОНТЕКСТІ ВІЙСЬКОВОЇ ПОЛІТИКИ ДОБИ ПРИНЦИПАТУ}

выяснена важность Ольвии для Рима в силу её удобного географического расположения как одной из звеньев сдерживающей системы севернопонтийских укреплений (limes Olbiopolitanus) для предотвращения нападений варварських племён. Показано, что стратегический комплекс Нижнего Побужья служил отдалённым прикрытием дунайской границы Римской империи. Он сдерживал проникновение варваров на Дунай и обеспечивал безопасность сухопутной дороги из Мёзии в Таврику. Доказано, что Ольвия занимала важное место в системе внешнеполитических связей Рима с Херсонесом и Боспорским царством и следовала в фарватере римской стратеги в данном регионе. Сделан вывод, что римское военное присутствие в Ольвии способствовало процветанию и ограждало город от нападений тавроскифов и сарматов.

Ключевые слова: Ольвия, Рим, Moesia Inferior, вексилляция, воины.

Вступ. Найважливішим завданням даного дослідження $є$ військовий аспект міжнародних стосунків Римської імперії з Ольвією. Археологічні знахідки останніх десятиліть дозволяють по-новому інтерпретувати зовнішньополітичну активність Риму в I-II ст. н. е. у Північному Понті. Враховуючи те, що тепер завдяки їм можна чіткіше простежити причини й напрями військової колонізації римлян на терени, які вважалися територією Barbaricum, нашим пріоритетним завданням $\epsilon$ більш ширше висвітлення військової складової зовнішньополітичних відносин Imperium Romanum з Ольвією. Важливим у цьому контексті $є$ й аналіз причин римського військового будівництва на території ольвійської хори.

Аналіз останніх досліджень і публікацій. Недостатня увага до цієї проблеми в радянський період, вже в часи незалежної України поступово зникає. Це пояснюється появою нових доказів українських археологів, які свідчать про проникнення римських військових підрозділів за межі союзної Ольвії [5; 6; 8]. Дослідження «Щасливого міста» римського часу розпочав ще Михайло Ростовцев своєю науковою розвідкою «Военная оккупация Ольвии Римлянами» (1915). Після жовтневого перевороту першим, хто повернувся до дослідження історії зв'язків цього полісу з Римом був В. Дьяков [3]. У радянський час цією тематикою займалися П. Каришковський, Д. Шелов [9], В. Зубар [4], С. Буйських [1], В. Крапівіна [7]. В незалежній Україні присутність римських військових підрозділів на території Нижнього Побужжя продовжує досліджувати С. Буйських та Р. Козленко [5; 6]. Виділимо й праці польських археологів, присвячених римським військам і їх укріпленням - фортам (castra), опорним пунктам (burgus), військовим таборам (castrum, castellum) та сторожовим постамвежам (praesidia) на території Північного Причорномор'я [10; 11].

Виділення невирішених раніше частин загальної проблеми, яким присвячується стаття. У літературі, присвяченій історії грецьких міст-держав 
Півдня України та стосунках цих полісів з Римською імперією, мало уваги приділяється саме їх військовій складовій. Цю лакуну вперше спробували заповнити В. Дьяков та Д. Шелов [3; 9]. Проте їхнє вирішення даної проблематики базувалося на тогочасному класовому підході, відштовхуючись від класиків марксизму-ленінізму. Ряд тверджень радянських істориків тепер вважаються застарілими у зв'язку 3 багатством сучасного археологічного матеріалу та новітніми дослідженнями сучасних учених. У першу чергу, ми виділяємо причини військової експансії Риму в напрямі північного сходу від провінції Мезія, які комплексно ще не були розглянуті. Також окреслюємо важливість посилення обороноздатності Ольвії у перших століттях нашої ери за безпосередньої участі Риму в контексті стратегії так званого «превентивного захисту» Pax Romana. Ïї сутність полягає в поступовому підпорядкуванні територій, які раніше знаходилися під дипломатичним впливом чи контролем, режиму прямого управління. Римські вояки починають будувати на варварських землях дороги, розміщувати там аванпости та сторожові вежі. Вперше виділено й основні етапи проникнення Риму на територію Ольвійської держави та детально описано іiі систему оборони. Ми також наголосили на значенні Ольвії та іiі укріплень для убезпечення кордонів імперії в II ст.

Формулювання цілей статті. Визначити причини і характер присутності римлян на території Ольвійської держави у I-II ст. н. е. в контексті військової політики доби Принципату. Метою є доведення важливості цього північнопонтійського міста як форпосту на периферії Pax Romana.

Виклад основного матеріалу дослідження. Уже перші легати Мезії велику увагу в своїй адміністративній діяльності звертали на становище греківколоністів північно-західного узбережжя Понту. Оволодіння цими територіями дозволяло римлянам стати повноправними господарями морського шляху на схід - в першу чергу на Кавказ, який став набувати для Риму, по мірі того, як розгорталася його боротьба з Парфією, все більше стратегічне значення в якості флангового плацдарму, і до гирл Дніпра та Дону [3, с. 87]. Варто відзначити не тільки військово-політичну причину зацікавленості Риму водними артеріями Бугу та Дніпра, а й торгівельно-економічну, адже Ольвійська держава розташовувалася на важливому сухопутному транспортному та торгівельному шляху. Він тягнувся від Дунаю до Дніпра і розгалужувався в напрямку Дону, прямував у Таврику і далі через Боспор на Північний Кавказ [1, с. 107].

Оскільки завоювання Мезії входило в загальний план генерального наступу Риму на Дунаї і останньому відводилася роль природного кордону, що перешкоджав би просуванню різноманітних варварських об'єднань, які проживали на північ і схід від нього, вкрай важливо було створення «буферних» зон на шляху до самого Дунаю. Потужна система оборони, яку планували створити римляни в гирлі Південного Бугу перед кочовим 


\section{ПРИСУТНІСТЬ РИМЛЯН НА ТЕРИТОРІЇ ОЛЬВІЙСЬКОЇ ДЕРЖАВИ У І-ІІ СТ. Н. Е. В КОНТЕКСТІ ВІЙСЬКОВОЇ ПОЛІТИКИ ДОБИ ПРИНЦИПАТУ}

масивом сарматів, могла відіграти роль одного з «передлімесів» для дунайського кордону імперії [1, с. 129].

У науковій літературі утвердилася думка, що аж до сер. І ст. н. е. контакти Ольвії з Римом обмежувалися лише романофільськими симпатіями представників окремих заможних родин, які зводили будівлі на честь римських імператорів [4, с. 22-25]. Існує припущення, що в часи війни Риму з Мітрідатом VIII, царем Боспору, командуючий експедиційними силами легат Мезії Авл Дідій Галл (Tac. Ann. 12.15.1), прийняв якесь важливе рішення стосовно Ольвії [2, с. $175 ; 7$, с. $66 ; 11$, с. 135]. У полісі було запроваджено нове літочислення, т. зв. ольвійську еру в 46 р. н. е. [1, с. 130; 4, с. 35-36; 4, с. 44; 5, с. 31-32].

Наступним етапом римсько-ольвійських стосунків став військовий союз між ольвіополітами та Тиберієм Плавтієм Сільваном, намісником Мезії в 57-67 pp. На ольвійській периферії починають з'являтися військові табори, що розташовувалися, ймовірно, уздовж сухопутної дороги з Мезії в Таврику. В. Дьяков припускає, що Ольвія могла бути вихідною базою для походу Плавтія Сільвана на допомогу Херсонесу [3, с. 92]. Саме з цим, найімовірніше, пов'язана поява в сер. І ст. військових таборів-кастеллумів - Дідова Хата III та Кам’янка V, що знаходилися неподалік сухопутного шляху з Мезії до Таврики і пізніше увійшли до системи укріплень на кордонах Ольвійської держави [1, с. 131; 4, с. 49; 5, с. 28; 6, с. 81]. У Дідовій Хаті III були знайдені уламки італійських амфор середини I ст., що свідчить про рівень тогочасної логістики римського війська $[1$, с. $100 ; 5$, с. 28; 6, с. 83]. За міркуваннями археолога Р. Козленка, після зведення Кам'янки V, підрозділ, що там розташовувався, під командуванням центуріона I Італійського легіону М. Емілія Люція Северина, просунувся далі й біля переправи на р. Південний Буг спорудив форт Дідова Хата III [6, с. 84]. Стосовно Кам'янки V, то судячи 3 планування та площі, цей castellum був розрахований на стаціонарну присутність 400-600 чоловік - cohors quingenaria. Розташований на високому степовому плато, біля 5-метрового кургану, немовби прикритий ним від відкритої частини степу, на вигідній стратегічній позиції, він утримував територію на північно-західному кордоні Ольвійської держави під основним валом, що перекривав прохід у глибину хори. Якщо ж ці табори будували різні центурії, то загальну кількість римських солдат на території Ольвійської держави в третій чверті I ст. можна було б визначити чисельністю cohors milliaria, тобто близько 1000 чоловік. Побудований неподалік від Анчекракської балки, яка в давнину слугувала притокою Березанського лиману, табір підтверджує вирішальну роль максимально облаштованої позиції у виборі місця закладення фортів навколо Ольвії. При участі, наприклад, у поході Т. Плавтія Сільвана римського флоту, фактор наявності поблизу укріплення з'єднаної з морем водної артерії, безумовно, мав велике значення. Високі кургани, біля яких було закладено Кам'янку V i Дідову Хату III, 


\section{ПРИСУТНІСТЬ РИМЛЯН НА ТЕРИТОРІЇ ОЛЬВІЙСЬКОЇ ДЕРЖАВИ У І-ІІ СТ. Н. Е. В КОНТЕКСТІ ВІЙСЬКОВОЇ ПОЛІТИКИ ДОБИ ПРИНЦИПАТУ}

використовувалися як дозорно-сигнальні пости для спостереження за навколишньою територією. Віддалено подібний до Кам'янки V є форт I ст. на території Британії, але набагато менший за площею та із одним внутрішнім укріпленням. Майже ідентичний табору Дідова Хата III та внутрішнім укріпленням Кам'янки V e castellum неподалік с. Бербоші, розташований біля переправи, при злитті р. Дунай та р. Сереет на території сучасної Румунії [6, с. 82]. Буйських С. класифікує Дідову Хату III як тимчасовий військовий табір, розрахований на 100 осіб, тобто на одну центурію за аналогією з табором «А» поблизу юдейської Масади [1, с. 88].

Також на користь появи в Ольвії римських військ в третій чверті I ст. свідчать надписи вищезгаданого центуріона вексилляції I Італійського легіону М. Емілія Северина та декрет на честь евоката Агафокла, а також археологічні знахідки речей римських вояків $[1$, с. $132 ; 4$, с. 47-48; 5 , с. $32 ; 6$, с. 83 ; 7, с. 72$]$. Є припущення, що Ольвійська держава тимчасово входила до складу Римської імперії між 62-69 pp. або мала певний статус в імперській політиці на зразок Тіри. Це припущення підсилюється відомостями Клавдія Птолемея про суттєве розширення на схід провінції Нижня Мезія (Ptol. Geogr. 3.10.7-9), які могли бути запозичені в більш раннього автора [6, с. 83-84].

За правління Траяна, десь між 106 і 111 рр. до Ольвії було направлено загін ауксілларіїв, озброєних продовгастими щитами, для захисту міста та околиці від сарматів. Скоріш за все, це були частини ХІ Клавдієвого легіону [1, с. 133]. Сарматські племена на той час загрожували не тільки Ольвійській державі, а й кордонам імперії. [4, с. 69, с. 102]. Після завершення своєї місії підрозділ auxilia було відряджено до однієї з місць постійної дислокації на територію провінції Moesia Inferior.

На початку принципату Адріана, охорону Ольвії певний час здійснював загін, виділений зі складу боспорського війська. Проте, як і попередній, він перебував там недовго [2, с. 173; 4, с. 102; 6, с. 79]. Відсутність сильних військових з'єднань, які б могли дієво захищати ольвійську хору, дозволила аланам в сер. II ст. знову здійснити напад. Проте система городищ «Щасливого міста» прийняла удар на себе і виконала своє основне завдання - столиця держави залишилася неушкодженою. Ольвіополіти виграли час і звернулися за допомогою до римлян. Антонін Пій вислав війська, які потіснили варварів (SHA. Ant. Pius. 9.9) [9, с. 60]. Таким чином, зав'язнувши в боротьбі 3 укріпленнями, варвари були змушені затриматися на території полісу і не змогли просунутися до Дністра та Дунаю, що й дозволило Антоніну вчасно прийти на допомогу з необхідними військовими силами [1, с. 135].

Уже із сер. II ст. в Ольвії починають розміщуватися значні військові 3’єднання, а саме вексилляції I Італійського, V Македонського, ХІ Клавдієвого легіонів та допоміжні загони фракійців під загальним командуванням центуріона 


\section{ПРИСУТНІСТЬ РИМЛЯН НА ТЕРИТОРІЇ ОЛЬВІЙСЬКОЇ ДЕРЖАВИ У І-ІІ СТ. Н. Е. В КОНТЕКСТІ ВІЙСЬКОВОЇ ПОЛІТИКИ ДОБИ ПРИНЦИПАТУ}

XI Клавдієвого легіону [4, с. 90; 4, с. 96]. Дані про відбування служби цих підрозділів на території Ольвійської держави відомі завдяки шести латинським надписам. Найважливішим з них є будівельний надпис М. Емілія Северина, де й згадуються прикомандировані в Ольвію вояки з мезійських легіонів [7, с. 74]. Їхнім завданням було не тільки локальне відбивання варварських набігів на поліс. У даному випадку мова йдеться про перетворення його в опорний пункт римського панування на підступах до володінь імперії, північний кордон яких за Антоніна Пія проходив уже не по Дунаю, а був переміщений на 350 км північніше.

Військова необхідність змусила римлян перейти від економічної та військової експансії до спроби відкритої колонізації. Першим кроком на цьому шляху й стало відправлення до Ольвії частин мезійської армії. Освоєння нижньобугського регіону здійснювалося римлянами достатньо грунтовно. Саме до сер. II ст. відноситься відбудова колишнього тимчасового військового табору в урочищі Дідова Хата і перетворення його в постійний castrum 3 баштами на кам'яних фундаментах $[1$, c. $67-68 ; 1$, с. 88]. Подібний табір було збудовано біля с. Дар’ївка на Інгульці [1, с. 88-89]. Про його призначення свідчить сам тип укріплень, що не мав аналогів ні у приольвійській зоні, ні в елліністичних укріпленнях Північного Причорномор'я в цілому [1, с. 88]. В Ольвії ж римлянами була зведена потужна цитадель - особливо укріплений оборонними стінами і баштами район міста 3 центральною спорудою командного пункту дислокованих військ - principia та будинком коменданта гарнізону - praetorium [1, с. 42-46; 10, с. 134-138; 11, с. 146]. Кістяком гарнізону були вояки ХІ Клавдієвого легіону [4, с. 92-93].

У 60-х - поч. 70-х pp. II ст. під наглядом римського військового архітектора та силами ольвійської вексилляції була збудована захисна стіна довжиною 61 м [4, с. 91]. Ця будівельна практика була традиційною для римської провінційної політики, адже в центрі регіону завжди зводився потужний базовий пункт, на побудову якого витрачалися основні зусилля - людські, фінансові та сировинні. У Дакії це була Сармицегетуза, в Нижній Мезії - Троезмис, у Тавриці - Херсонес [1, с. 135].

Важливим елементом римської колонізації були coloniae militum - тобто виведення в колонії ветеранів, які звільнилися зі служби, та наділення їх землею, що сприяло створенню соціальної бази влади римлян у нових регіонах. Поселенням ветеранів-легіонерів на ольвійській хорі, можливо було Козирське городище [1, с. 59-62]. Про це свідчить, зокрема, використання прийомів римської будівельної техніки, застосування обпаленої цегли; наявність вапняногіпсових карнизів і фрескових розписів, характерних для пунктів розміщення римських військ у сер. II - сер. III ст. в Аквінкумі, Бригеціо, Інтерцизі та Карнкнтумі. Доведено, що проживаючі тут ветерани досить вдало копіювали 


\section{ПРИСУТНІСТЬ РИМЛЯН НА ТЕРИТОРІЇ ОЛЬВІЙСЬКОЇ ДЕРЖАВИ У І-ІІ СТ. Н. Е. В КОНТЕКСТІ ВІЙСЬКОВОЇ ПОЛІТИКИ ДОБИ ПРИНЦИПАТУ}

римську будівельну традицію, яка в Козирці фіксувалася вперше, враховуючи те, що поселення знаходилося на периферії імперії. Це дозволяє повернутися до дискусійної теми стосовно масштабів римських впливів або романізації найближчих до кордонів Римської держави територій [8, с. 54].

Також можливо, що частина вояків розміщувалася і в ін. городищах, зокрема в Скельці. Вона являла собою найбільш яскравий приклад застосування римського військово-інженерного будівництва земляних укріплень на території Ольвійської держави [1, с. 69-74]. Тут було знайдено рельєф, присвячений фракійським богам, що свідчить про перебування там військових 3 придунайських провінцій [4, с. 99-101] .

Різке збільшення кількості фракійських імен в Ольвії 3 сер. II ст., проникнення в місто ряду характерних елементів фракійської культури говорить про те, що більша частина римських військових тут була фракійського походження [1, с. 136-137].

Наприкінці др. пол. ІІ ст. розрізнені вексилляції римських військ починають підпорядковуватися єдиному командуванню під керівництвом військового трибуна, що сприяло посиленню позицій римлян в ПівнічноЗахідному Причорномор'ї і зміцненню зовнішньо-політичного становища самої Ольвії [1, с. 137-138; 4, с. 95].

Також варто зазначити, що поряд із вояками auxilia, в полісі дислокувалася й певна кількість легіонерів, про що свідчить надгробок, поставлений наприкінці II ст. Галерієм Монтаном. Особливо цікавим у даному випадку є те, що Галерій був не простим солдатом ХІ Клавдієвого легіону, а згідно Rangordnung перебував у званні armatura, яке надавали воякам, що пройшли спеціальний курс вишколу. Військовослужбовці, що займали цю посаду в легіонах ставали, свого роду, інструкторами новобранців. За своїм посадовим становищем вони були принципалами і стояли в одному ряді з такими офіцерами як signifier, optio, tesserarius, tubicen і т. д. Тому можна припустити, що Галерій Монтан повинен був відповідати за тактичну підготовку вояків ольвійської вексилляції [4, с. 103-104; 7, с. 76].

Варто згадати й про знахідку у південно-східній частині цитаделі Ольвії військового диплому, виданому ветеранові Мезійської Флавієвої ескадри (Classis Flavia Moesica), що проходив службу на одному 3 кораблів гарнізону, розміщеному в місті за часів Антоніні Пія. Цей диплом дозволяє визначити, що римські солдати дислокувались в Ольвії ще задовго до 157 р., адже важко пояснити, чому ветеран, звільнений у відставку вважав за краще залишитись тут, а не відправитися на батьківщину [7, с. 75-76].

Отже можна виділити два основні етапи присутності римських військ на території Ольвійської держави періоду Принципату (I-II ст. н. е.). Перший етап пов'язаний з походом мезійського намісника Т. Плавтія Сильвана на допомогу 


\section{ПРИСУТНІСТЬ РИМЛЯН НА ТЕРИТОРІЇ ОЛЬВІЙСЬКОЇ ДЕРЖАВИ У І-ІІ СТ. Н. Е. В КОНТЕКСТІ ВІЙСЬКОВОЇ ПОЛІТИКИ ДОБИ ПРИНЦИПАТУ}

оточеному скіфами Херсонесу і визначається появою системи ольвійських укріплених пунктів та фортець. Саме $з$ цим пов'язана поява в третій чверті I ст. військових таборів - Дідова Хата III та Кам'янка V. Їх побудова на ольвійській хорі, а пізніше й створення «передлімесної» системи, що розташовувалися поряд iз сухопутною дорогою з Мезії в Таврику пояснюється потребою у потужній системі оборони, яку створили римляни на Гіпанісі для убезпечення від кочового масиву сарматів. Т. зв. «передлімес» або Limes Olbiopolitanus міг відіграти роль однієї з передових ліній для захисту дунайського кордону імперії від набігів варварів.

Другий етап характеризується серединою II ст., коли в Ольвійській державі починають розміщуватися значні військові сили, а саме вексилляції I Італійського, V Македонського, ХІ Клавдієвого легіонів та допоміжні загони фракійців під загальним командуванням центуріона ХІ Клавдієвого легіону. У цей час Ольвія перетворюється в опорний пункт римського панування на підступах до володінь Римської імперії, адже північний кордон держави за Антоніна Пія посунувся значно північніше від Дунаю. У місті римлянами була зведена кам'яна цитадель, гарнізон якої складався 3 вояків ХІ Клавдієвого легіону. Археологічні знахідки дозволяють припустити й наявність на території ольвійської хори поселення колоністів-римлян з числа відставних вояків.

Висновки $з$ даного дослідження і перспективи подальшого розвитку в цьому напрямі. Система ольвійських каструмів була важливою і необхідною ланкою в загальному ланцюгу північнопонтійських укріплень задля прикриття північно-східного кордону Римської імперії разом з Limes Moesia. Дунай бачився в очах римських стратегів важливою природною межею між імперією та варварським світом, значення якої не змінюється навіть з утворенням провінції Дакія. Недарма саме там у період Ранньої імперії зосереджується найбільша чисельність вояків, а це приблизно 200 тис. чоловік - майже половина усього римського війська. Важливість Істру як фронтиру в II ст. підкреслює й римський історик Геродіан (Herod. 2.9.1). Стосовно унікальності ольвійської захисної системи, яка складалася 3 фортечних укріплень самого міста та комплексу городищ разом із недавно виявленими фортами, то вищенаведене дозволяє застосувати до неї термін limes [6, с. 84]. Такий ланцюговий тип захисту був характерним не лише для території сучасного Півдня України, а це Limes Tauricus, Нижній вал Бессарабії, захисна система Боспору а й стосувався інших укріплень прямокутної форми, що знаходилися на відстані світлового зв'язку. Були відкриті подібні системи городищ-форпостів біля Танаїсу, на Закавказзі, Нижній Мезії, Дакії, Германії [1, с. 110-111]. Будівництво т. зв. Ольвійського лімесу могло слугувати своєрідним прикриттям дунайського кордону. А це вказує на важливість Ольвії для системи безпеки тогочасної Pax Romana. Тут варто згадати один важливий ольвійський надпис I ст., де мова йде про 


\section{ПРИСУТНІСТЬ РИМЛЯН НА ТЕРИТОРІЇ ОЛЬВІЙСЬКОЇ ДЕРЖАВИ У І-ІІ СТ. Н. Е. В КОНТЕКСТІ ВІЙСЬКОВОЇ ПОЛІТИКИ ДОБИ ПРИНЦИПАТУ}

будівництво споруд, які повинні забезпечити полісу «вічну безпеку» (sic!). Ці слова навряд чи могли стосуватися лише міських кріпосних споруд. Не виключено, що надпис натякав не лише на увесь пояс укріплень і опорних пунктів, створених навколо Ольвії, а й на потужний оборонний вал із ровом на північному уразливому прикордонні хори, який був виявлений ще на поч. XX ст. В останньому випадку вислів «вічна безпека» виглядає більш виправданим. Адже зі сходу, заходу і півдня держава оточена потужними природними водними перешкодами і ланцюгом прибережних укріплень, а з півночі рівнина межиріччя Березанського і Бугського лиманів була перерізана штучним оборонним рубежем [1, c. 114-115]. А це і $\epsilon$ ще одним підтвердженням внеску Риму 3 його організацією передових систем оборони в справу існування і процвітання Ольвії. Саме серйозні оборонні заходи за підтримки військових з'єднань 3 провінції Мезія забезпечили те, що «Щасливе місто», незважаючи на всю складність взаємовідносин 3 навколишніми племенами, так і не було завойовне варварами аж до готської навали [1, с. 142].

Детальне вивчення зв'язків Риму 3 грецькими містами-державами Північного Причорномор'я, зокрема їхньої ролі і значення у системі зовнішньої політики імперії перших століть нашої ери матиме важливе значення при проведенні подальших досліджень.

\section{Список використаних джерел:}

1. Буйских С. Б. Фортификация Ольвийского государства (первые века нашей эры) / С. Б. Буйских. - Киев : Наук. думка, 1991. - 161 с.

2. Винокуров Н. И. Римская политика в Северном и Северо-Западном Причерноморье в середине І в. н. э. / Н. И. Винокуров, С. М. Крыкин // Проблемы истории, филологии, культуры. - 2017. - № 4. - С. 170-194.

3. Дьяков В. Н. Оккупация Таврики Римом в І в. н. э. / В.Н.Дьяков // ВДИ. - 1941. - № 1. - С. 87-97.

4. Зубарь В. М. Северный Понт и Римская империя (середина І в. до н. э. - первая половина VI в.) / В. М. Зубарь. - Киев : Ин-т археологии, 1998. $-200 \mathrm{c}$.

5. Козленко Р. А. Римский форт на границе Ольвийского государства / P. А. Козленко // LAUREA I. Античный мир и средние века: Чтения памяти профессора Владимира Ивановича Кадеева : материалы. - Харьков : НТМТ, 2015. - C. 28-33.

6. Козленко Р. О. Римські форти на території Ольвійської держави / Р. О. Козленко // Археологія. - 2016. - № 2. - С. 78-87.

7. Крапівіна В. В. Ольвія Понтійська. Греко-римський та пізньоантичний періоди / В. В. Крапівіна. - Київ : Вид. О. Філюк, 2014. - 358 с. 
8. Сон Н. А. TEGULA ROMANA из поселения Козырка близ Ольвии (к вопросу о римской строительной традиции в Северно-Западном Причерноморье) / Н. А. Сон, А. В. Буйских // Археологія і давня історія України. - 2014. Вип. 1 (12). - С. 48-54.

9. Шелов Д. Б. Римляне в Северном Причерноморье во ІІ в. н. э. / Д. Б. Шелов // ВДИ. - 1981. - № 4. - С. 52-63.

10. Karasiewicz-Szczypiorski R. Forty i posterunki rzymskie w Scytii i Taurydzie w okresie pryncypatu / R. Karasiewicz-Szczypiorski. - Warszawa : Instytut Archeologii Uniwersytetu Warszawskiego, 2015. - 209 s.

11. Sarnowski T. Wojsko rzymskie w Mezji Dolnej i na północnym wybrzeżu Morza Czarnego / T. Sarnowski. - Warszawa : Wydawnictwo Uniwersytetu Warszawskiego, 1988. - $220 \mathrm{~s}$.

\section{References:}

1. Buyskikh, S.B. (1991). Fortification of Olbia of the state (first ages of our era), Kyiv : Naukova dumka.

2. Vinokurov, N.I. (2017). Roman policy in North and North-Western Pontic littoral. Problemy istorii, filologii, kultury [Problems of history, philology, culture], no. 4, pp. 170-194.

3. Diakov, V. N (1941). Occupation of Taurica by Rome in I A.D. Vestnik drevney istorii [Bulletin of ancient history], no. 1, pp. 87-97.

4. Zubar, V.M. (1998). North Pont and Roman empire (middle I B.C. - first half of VI A.D.), Kyiv: Naukova dumka.

5. Kozlenko, R.A. (2015). Roman forts on the territory of the Olbia state. LAUREA I. Ancient world and Middle ages : Reading of memory of professor Vladimir Ivanovich Kadeev. Materials, Kharkov: OOO «NTMT», pp. 28-33.

6. Kozlenko, R.O. (2016). Roman forts on the territory of the Olbia state. Arkheologiya [Archaeology], no. 2, pp. 78-87.

7. Krapivina, V.V. (2014). Olbia Phontic. Greek-Roman and Late antiquity period. Kyiv: Publisher Oleh Filuk.

8. Son, N.A. (2014). TEGULA ROMANA from the settlement of Kozyrka near Olbia (to the question about Roman build tradition in North-Western Pontic littoral). Arkheolohiya I davnya istoriya Ukrayiny [Archaeology and old history of Ukraine], no. 1 , is. 12 , pp. $48-54$.

9. Shelov, D.B. (1981). Romans in Pontic littoral in II A.D. Vestnik drevney istorii [Bulletin of ancient history], no. 4, pp. 52-63.

10. Karasiewicz-Szczypiorski, R. (2015). Forty i posterunki rzymskie w Scytii i Taurydzie $w$ okresie pryncypatu. Warszawa: Instytut Archeologii Uniwersytetu Warszawskiego. 
ПРИСУТНІСТЬ РИМЛЯН НА ТЕРИТОРІЇ ОЛЬВІЙСЬКОЇ ДЕРЖАВИ У І-ІІ СТ. Н. Е. В КОНТЕКСТІ ВІЙСЬКОВОЇ ПОЛІТИКИ ДОБИ ПРИНЦИПАТУ

11. Sarnowski, T. (1988). Wojsko rzymskie w Mezji Dolnej i na północnym wybrzeżu Morza Czarnego. Warszawa: Wydawnictwo Uniwersytetu Warszawskiego.

(C) Олійник М. А., 2018 